\title{
"Everything for Sale!” Contract Law in the Context of the Moral Misery of the Modern West
}

\author{
Professor Dr. Jacek Mazurkiewicz \\ University of Zielona Góra, Poland
}

Doi: 10.19044/elp.v6no1a1

URL:http://dx.doi.org/10.19044/elp.v6no1a1

\begin{abstract}
The article contains a critical evaluation of the moral and social function of contract law. It shows the breaking of the principle of the equality of parties. Moreover, the examples of making contracts of what belongs to the fundamental human goods are also revealed. It presents violations of the principle of trust of parties that conclude contracts as a result of state intelligence operations. The paper exposes the use of electronic manipulation, because of which a weaker party of the contract is often helpless. Attention was also paid to the development of economic and commercial sanctions, which repeatedly frustrates the principle of freedom of economic activity.
\end{abstract}

Keywords: Contract law, morality, equality of subjects, freedom of contract, business intelligence, electronic manipulation, economic sanctions.

To Zosia ${ }^{1}$

\section{Introduction}

Concluding contracts is not only a legal and economic phenomenon. It is subject to multiple conditions, including political ones. My paper is an attempt to analyze the foundations of contract law in contracting practice. It

\footnotetext{
1 To Zosia Zaporowska who during the NATO assault on Yugoslavia was probably the youngest war correspondent in the world, because was then only 18-year-and-one and a half months-old war and obtained an accreditation by the Press Center of the Yugoslav Army (Ратна прес карта. War Press Card Бр. 1935). She is a lawyer with original achievements concerning primarily the situation of horses and their users under both private and public law. She publishes, together with sister Maria, the first inquisitive legal analysis of the institution of waqf in Poland and co-authored the most comprehensive monograph on Polish regulations concerning legal names. She has publisher not only in Polish legal journals as "Przegląd Sądowy", "Palestra", "Rejent”, "Radca Prawny”, "Prawo i Podatki”, "Studia Prawnicze. Studia i Materiały", "Ochrona Środowiska. Prawo i Polityka”, also in monographs, Festschrift and other than periodicals, including in Arab, Belarusian, Ukrainian and Hebrew. Moreover, she has been a freelance journalist, a globetrotter, a social activists, an animal protector, an artist, and an entrepreneur.
} 
mainly concerns legal aspects, but it shows the status quo that goes beyond what is the subject of the main interest of contract law scholars.

\section{I}

The entry into force of the Austrian Civil Code (Allgemeines bürgerliches Gesetzbuch, ABGB) was accompanied by a conviction of its extraordinary value and role. ${ }^{2}$

It caused - it is hard to say that it resulted - the marginalization of ethical, philosophical and historical reflection on Austrian civil law. ${ }^{3}$

As an eminent Polish lawyer of the late nineteenth and the beginning of the twentieth century, Ignacy Koschembahr-Łyskowski, wrote, the Austrian "law faculties were only interested in «the production of officials»". 4

2 Cf. K. Sójka-Zielińska, Wielkie kodyfikacje cywilne w XIX wieku, Warszawa 1973, pp. 6566; J. Mazurkiewicz, "Recenzja pracy K. Sójki-Zielińskiej pt. Wielkie kodyfikacje cywilne w XIX wieku”, Przeglad Prawa i Administracji, 1976, Vol. VII, p. 266.

3 As E. Till pointed out, the legal scholars at the time, "saw nothing but the dead letter of the law given by «the supreme legislator», they limited themselves to the dry interpretation of the letter, considering all criticism and even the de lege ferenda conclusions as a mere insult to the majesty”: E. Till, J. Unger - Wpływ jego na naukę prawa prywatnego, Lwów 1913, p. 5. Cf. K. Sójką-Zielińską, Wielkie kodyfikacje..., s. 66; zob. także K. Sojka-Zielińska, Wielkie kodyfikacje..., p. 156; I. Koschembahr-Łyskowski, "Pojęcie prawa". In Księga pamiatkowa ku uczczeniu 250-tej rocznicy założenia Uniwersytetu Lwowskiego przez króla Jana Kazimierza r. 1661, Vol. I, Lwów 1912, p. 63. Por. A. Stelmachowski, Wstęp do teorii prawa cywilnego, Warszawa 1969, pp. 116-117, (here about the views of C. Demolombe and the statement attributed to M. Buguet); A. Stelmachowski, Wstęp do teorii prawa cywilnego, Warszawa 1984, p. 144; cf. W. Wołodkiewicz, "Studia prawnicze - nauka przepisów czy nauka prawa”. In P. Niczyporuk, A. Tarwacka (eds.), Noctes iurisprudentiae. Scritti in onore di Jan Zabłocki, Białystok 2015, pp. 310, 312 (I would like to thank A. A. Novikow from the Sankt-Petersburg State University for drawing my attention to this article and presenting me the book).

4 I. Koschembahr-Łyskowski, O stanowisku prawa rzymskiego w powszechnej ustawie cywilnej dla cesarstwa austriackiego, Lwów 1911, p. 161. During the 6th National Congress of Civil Lawyers in Międzyzdroje, in a discussion after my lecture, Professor Fryderyk Zoll referred to this in a friendly statement, but criticized my "too broad" perspective. I replied that I see the advantage of my paper in the attempt to raise the awareness of civil lawyers of the need to apply the Hegelian incentive to perceive the studied matter in all-encompassing connection of things and phenomena, although such a perspective is ridiculed today due to political correctness (moreover, I do not share the sympathetic criticism expressed by Professor Wojciech Popiołek that "civil law does not exist": I still think so). I did not share the opinion that the formation of "machines for subsuming" was mainly German specialty. Certainly, I do not question the value of the subsumption itself, although such an attitude was somewhat suggested to me. I see misery only in the dictatorship of subsumption... Professor Adam Olejniczak presented a friendly remark, that in addition to the Western misery, I should also the misery of East. I should answer that it will be a difficult to challenge my views, an esteem for the East has lasted for millennia: church altars, entrances to the cottages, the laying of corpses at cemeteries, and even - what is definitely incorrect today - the word "orientation" have, after all, non-incidental origins. 
This led to the formation and, ultimately, spread of legal positivism, whose intellectually universal, the latest formulation was the view of Kelsen's Vienna Circle.

The revolutionary concepts of Rudolf von Jhering ${ }^{5}$ and Léon Duguit ${ }^{6}$ - although of almost archaic provenience - were the reaction to legal positivism. Moreover, not only shocking and fascinating, but absolutely critical analysis and assessment of English workers' legislation presented in the priceless work of Fryderyk Engels, ${ }^{7}$ which an obvious complement to the

5 In particular, cf. R. von Jhering, Geist des römischen Rechts auf den verschiedenen Stufen seiner Entwicklung, Vol. III, Leipzig 1865, passim; R. von Jhering, Der Kamp um's Recht, Wien 1874, passim; R. von Jhering, Der Zweck im Recht, Leipzig 1893, passim. Cf. also: A. Stelmachowski, Wstęp do teorii prawa cywilnego, Warszawa 1969, p. 117. I would like to thank Basia Bernfeld from Vienna for German-language Internet queries and translations from German, above all for her advice, suggestions, critical remarks and assistance in proofreading and preparing the bibliography.

6 In particular, cf. L. Duguit, L'état, le droit objectif et la loi positive, Paris 1901, passim; L. Duguit, Traité de droit constitutionel, Vol. I, Paris 1921, passim; L. Duguit, Kierunki rozwoju prawa cywilnego od początku XIX wieku, translation by S. Sieczkowski, Warszawa-Kraków 1938, passim. Cf. A. Stelmachowski, Wstęp do teorii..., 1969, p. 118.

7 "But rightly to measure the hypocrisy of these promises, the practice of the bourgeoisie must be taken into account. We have seen in the course of our report how the bourgeoisie exploits the proletariat in every conceivable way for its own benefit! We have, however, hitherto seen only how the single bourgeois maltreats the proletariat upon his own account. Let us turn now to the manner in which the bourgeoisie as a party, as the power of the State, conducts itself towards the proletariat. Laws are necessary only because there are persons in existence who own nothing; and although this is directly expressed in but few laws, as, for instance, those against vagabonds and tramps, in which the proletariat as such is outlawed, yet enmity to the proletariat is so emphatically the basis of the law that the judges, and especially the Justices of the Peace, who are bourgeois themselves, and with whom the proletariat comes most in contact, find this meaning in the laws without further consideration. If a rich man is brought up, or rather summoned, to appear before the court, the judge regrets that he is obliged to impose so much trouble, treats the matter as favourably as possible, and, if he is forced to condemn the accused, does so with extreme regret, etc., etc., and the end of it all is a miserable fine, which the bourgeois throws upon the table with contempt and then departs. But if a poor devil gets into such a position as involves appearing before the Justice of the Peace - he has almost always spent the night in the stationhouse with a crowd of his peers - he is regarded from the beginning as guilty; his defence is set aside with a contemptuous "Oh! we know the excuse", and a fine imposed which he cannot pay and must work out with several months on the treadmill. And if nothing can be proved against him, he is sent to the treadmill, none the less, "as a rogue and a vagabond". The partisanship of the Justices of the Peace, especially in the country, surpasses all description, and it is so much the order of the day that all cases which are not too utterly flagrant are quietly reported by the newspapers, without comment. Nor is anything else to be expected. For on the one hand, these Dogberries do merely construe the law according to the intent of the farmers, and, on the other, they are themselves bourgeois, who see the foundation of all true order in the interests of their class. And the conduct of the police corresponds to that of the Justices of the Peace. The bourgeois may do what he will and the police remain ever polite, adhering strictly to the law, but the proletarian is roughly, brutally treated; his poverty both casts the suspicion of every sort of crime upon him and cuts 
most important 19th-century opus, Capital of Karl Marx, should be seen in the same light. Despite these efforts of eminent intellectuals, was the depreciation of the moral and social context of law, including civil law, led to the abhorrent phenomenon which was the law of the Third Reich.

I was not saying this at the end of September 2016 during the 6th National Congress of Civil Lawyers in Międzyzdroje without a significant reason. Although I am completely aware of the obvious difference in proportions, I am anxiously looking at modern civil law which is increasingly losing its ethical and social dimension, losing its moral and social function.

\section{II}

The principle of equality of entities was pointed out among the foundations of civil law, and perhaps especially the basis of contract law.

him off from legal redress against any caprice of the administrators of the law; for him, therefore, the protecting forms of the law do not exist, the police force their way into his house without further ceremony, arrest and abuse him; and only when a working-men's association, such as the miners, engages a Roberts, does it become evident how little the protective side of the law exists for the working-man, how frequently he has to bear all the burdens of the law without enjoying its benefits": F. Engels, Condition of the Working Class in England, pp. 185-186; https://www.marxists.org/archive/marx/works/download/pdf/condition-workingclass-england.pdf. How missing today is a scholar in Poland who would like to analyse the condition of the slaves of the early 21st century precariat. The examples of them could be my $\mathrm{PhD}$ student who for over a year of hard work did not get a penny from the law office in which he worked, and some others, about whom I heard from a reliable source, who have to pay the patron for the opportunity to work in the law office. Similarly missing is a scholar who would like to take the trouble to show the real roots of the jurisprudence of Polish courts approving the immoral interpretation of the easing of transmission (Article $305^{1}$ of Polish Civil Code), which is in favour of large corporations. To show the state of freedom of research activity in Poland after 1989, I would add I did not find the 1952 Polish edition of Friedrich Engels' Condition of the working class in England. It is worth mentioning the story that I heard from an old librarian, that years ago, at the time of grotesque de-communization, the works of Marx and Engels were thrown through the window from the University Library in Wroclaw at Karol Szajnocha Street (I was surprised by the "publicity" of this practice, but I was later informed that this was a window not facing the street). Moreover, I was told by the late rector of the Wrocław University, Professor Józef Łukasiewicz, that many mathematical works in Russian were similarly thrown out, and lately university mathematicians asked about them. Similar attitudes were not something exceptional among librarians in these days. Cf. Z. Zaporowska, M. Matusiewicz, “Narodowcy z Narodowej”, Nie, No. 2004/50, p. 3 
Although it has always been a fiction from an economic point of view, ${ }^{8}$ today it is also a fiction in the juridical dimension. ${ }^{9}$

What equality of entities could be observe between a consumer and a corporation, as a great supra-state organizational structure of the capitalists is called (because of not disinterested love for euphemisms)? 10 Who today has the sensitivity of the Jewish grandfather of Antek Słonimski, who taught French to his grandson, in future a noted Polish poet, and said to him: "société: that means a gang!"?

On the one side there is a helpless man, 11 and an organization having the taboo of market psychologists, marketers ready for almost everything, for whom an ordinary customer is the target, informally known as a gull, is on the other side. ${ }^{12}$

8 Several decades ago, Professor Andrzej Stelmachowski warned: "the legal principle of equality - specific to civil law - can give socially useful results only in the absence of significant economic differences. With existing inequalities, it only deepens the advantage of the stronger over the weaker. In the nineteenth century, this was expressed primarily in the exploitation of the workers' masses by capitalist entrepreneurs; the merits of the classics of Marxism were the unmasking, the disclosure of the operation of this mechanism": A. Stelmachowski, Wstep do teorii..., 1969, p. 82.

9 As noted by A. Stelmachowski, "the equivalence of entities means in civil law only the lack of administrative («state») subordination”: A. Stelmachowski, Wstep do teorii..., 1969, p. 34. Cf. also: ibid., p. 35, with an extensive, approving quotation from Marx' The Critique of the Gotha Program (Kritik des Gothaer Programms). Cf. K. Marks, "Krytyka Programu Gotajskiego”. In K. Marks, F. Engels, Dzieła, Vol. 19, Warszawa 1972, pp. 36-38.

10 Professor Jerzy Poczobut approvingly referred to this during the 6th National Congress of Civil Lawyers in Międzyzdroje, in the discussion after my paper. Professor Poczobut mentioned about the related context of Stanisław Sołtysiński's publication, which, however, concerned the unequal situation of companies competing with the corporations which are supported by the state, and that the latter not infrequently effectively influence the shape of national legislation. Cf. S. Sołtysiński, "O potrzebie powstrzymania procesów nierównego traktowania podmiotów gospodarczych”, Kwartalnik Prawa Prywatnego 2015, No. 3, pp. 493 fff; cf. also: S. Sołtysiński, "Ład korporacyjny w świetle lekcji kryzysu”, Kwartalnik Prawa Prywatnego 2011, No. 1, pp. 47 ff..; "Uhonorowanie Profesora Stanisława Sołtysińskiego, streszczenie wykładu S. Sołtysińskiego pt. Ład korporacyjny w świetle lekcji kryzysu", Przeglad Prawa Handlowego 2010, No. 6, s. 4 ff. I knew this paper before; cf. P. Zaporowski, J. Mazurkiewicz (ed.), M. Zaporowska, Z. Zaporowska, Polskie prawo firmowe. Zagadnienia wybrane, Wrocław 2016, p. 340, footnote 1165 ; p. 700, footnote 2462; p. 884, footnote 3149 ; p. 921, footnote 3266; http://www.bibliotekacyfrowa.pl/dlibra/docmetadata?id=76594\&from=publication.

11 It is obvious that this helplessness is our fate - not only and not primarily - in the sphere of contract law. Cf. J. Mazurkiewicz, "Co może obywatel w demokratycznym państwie prawnym?”. In J. Mazurkiewicz, J. Mazurkiewicz, M. Zaporowska, Z. Zaporowska, “Wieniec laurowy dla Profesora Jerzego Ignatowicza (pięć prawniczych miniatur)”. In M. Nazar (ed.), Prawo cywilne - stanowienie, wyktadnia i stosowanie. Ksiega pamiatkowa dla uczczenia setnej rocznicy urodzin Profesora Jerzego Ignatowicza, Lublin 2015, pp. 239-240.

12 Cf. P. Reszka, Chciwość. Jak nas oszukuja wielkie firmy, Warszawa 2016, passim. Cf. also: M. Zimmerman, "Być rekinem i zjadać frajerów, czyli jak nas oszukały wielkie firmy", 
Abusive clauses turn out to be almost void of legal significance. In glory of respect for the law, a trash can be sold, and sometimes even really "nothing" can be sold with the benefit for corporations!

Who, among the normal buyers of an (alleged) insurance policy, is able to find out at the time of conclusion of the contract, that on the page 87 of booklet written in small print, containing the general terms and conditions of the insurance contract (although he confirmed with his own signature the he read them), there is a provision which makes this insurance is a fiction for him? This provision excludes responsibility in the case of chronic diseases, and someone who - like me - is 67 years old most often has some chronic disease.

An ordinary man cannot afford the commission of a legal expertise concerning a contract worth, let's say, 65 zlotys (15 euros), while a corporation is preparing for this contract for a long time and deadly seriously.

Many examples taken from the praxis of contract law show that the equality of entities is - even undisclosed - masquerade! And a chatter of some scholars about this equality reminds literally the beating of foam. ${ }^{13}$

\section{III}

The regulations that oblige the contracting parties to respect confidentiality or, more broadly, to respect for good manners can be pointed out. Such regulations are contained in the Polish Civil Code, in particular in Article $70^{5}$, Article $72 \S 2$, whether art. $72^{1}$. The effects provided for in art. 58 para. 2 of this Code $^{14}$ should be also mentioned. ${ }^{15}$

http://biznes.onet.pl/wiadomosci/finanse/jak-oszukuja-wielkie-firmy-bankowcy-agenciubezpieczeniowi/q8v7m5.

13 In another area, Andrzej Stelmachowski wrote and unsuccessfully warned about similar objectification of the weaker subject of the employment relationship. Cf. A. Stelmachowski, Kościół katolicki w Polsce wobec wyzwań liberalizmu, Lublin 1996, p. 21.

14 "Legal action contrary to the principles of social coexistence is void".

15 Cf. A. Olejniczak, "O ochronie poufności negocjacji w świetle art. 721 Kodeksu cywilnego”. In A. Brzozowski, W. Kocot, K. Michałowska (eds.), W kierunku europeizacji prawa prywatnego. Ksiega pamiatkowa dedykowana profesorowi Jerzemu Rajskiemu, Warszawa 2007, pp. $35 \mathrm{ff}$ (particularly the conlusion on page 50); P. Machnikowski, Prawne instrumenty ochrony zaufania przy zawieraniu umowy, Wrocław 2010, pp. 185 ff.; K. Kopaczyńska-Pieczniak. In A. Kidyba (ed.), Kodeks cywilny. Komentarz, Vol. I, Część ogólna, Warszawa 2012, pp. 495 ff., 510 ff.; A. Janiak. In A. Kidyba (ed.), Kodeks cywilny. Komentarz, Vol. I, Część ogólna, Warszawa 2012, pp. 351 ff.; M. Safjan. In K. Pietrzykowski (ed.), Kodeks cywilny, Vol. I: Art. 1-44910, Warszawa 2013, pp. 255 ff.; A. Brzozowski. In M. Safjan. In K. Pietrzykowski (ed.), Kodeks cywilny, Vol. I: Art. 1-44910, Warszawa 2013, pp. 311-312, 314 ff.; P. Księżak. In M. Pyziak-Szafnicka, P. Księżak (eds.), Kodeks cywilny. Część ogólna, Warszawa 2014, pp. 661 ff.; W. Robaczyński In M. Pyziak-Szafnicka, P. Księżak (eds.), Kodeks cywilny. Część ogólna, Warszawa 2014, pp. 872 ff.; M. PyziakSzafnicka. In M. Pyziak-Szafnicka, P. Księżak (eds.), Kodeks cywilny. Część ogólna, 
But how can protect herself the party when the other party obtains the support of the state which is an initiator, co-creator and user of the Echelon system? ${ }^{16}$ And today undoubtedly better and more effective systems, not only Prism and Tempora. ${ }^{17}$

Every phone call, every text message, every fax and every e-mail, including every message spoken, written or sent by people who listened to me in Międzyzdroje, or anyway and anywhere (not only in Zielona Góra, Brno, Kiev, Poznań, Saint-Petersburg, Prague and Wroclaw), is checked and all information contained in them, which may be used by the Echelon system administrator, are collected and stored.

It has long been known that the pieces of information stolen by the Echelon system, which is the invention of our "beloved ally", are also used in business intelligence, including, and perhaps even above all, during the concluding of contracts. ${ }^{18}$ The largest contracts.

Warszawa 2014, pp. 887 ff., 899 ff.; P. Machnikowski. In E. Gniewek, P. Machnikowski (eds.), Kodeks cywilny. Komentarz, Warszawa 2014, pp. 141-141, $201 \mathrm{ff}$.

16 See the first in the Polish professional literature attempt to analyse the legal spects of Echelon: M. Andreasik, D. Karkut, B. Mierzwiński, J. Mazurkiewicz, M. Popielas, K. Trzeciak, M. Zaporowska, Z. Zaporowska, "Orwell w realu, czyli o systemie Echelon z perspektywy polskiego prawa”, Studia Prawnicze. Rozprawy i Materiaty 2014, No. 2, pp. 55 ff. (this article waited several years and finally could appear in this journal). Cf. "Echelon”, https://en.wikipedia.org/wiki/ECHELON ("In the early 1990s, the U.S. National Security Agency intercepted the communications between the European aerospace company Airbus and the Saudi Arabian national airline. In 1994, Airbus lost a \$6 billion contract with Saudi Arabia after the NSA, acting as a whistleblower, reported that Airbus officials had been bribing Saudi officials to secure the contract. As a result, the American aerospace company McDonnell Douglas (now part of Boeing) won the multibillion-dollar contract instead of Airbus”); M. Simoner, Die Allesfresser der Spionage, http://derstandard.at/1369363266451/Die-Allesfresser-der-Spionage... And among Koszmarny sen Snowdena: w Holandii opracowano wlasna wersje „,pakietu Jarowej”, https://pl.sputniknews.com/opinie/201611074198491-snowden-pakiet-jarowej-holandia/

17 Cf. dkl, DPA, NSA sorgte schon vor 9/11 für Ärger, http://www.n24.de/n24/Wissen/Technik/d/3070112/nsa-sorgte-schon-vor-9-11-fueraerger.html.

18 Cf. S. Schmitt, "Wirtschaftsspionage”, http://www.sueddeutsche.de/digital/streitum-echelon-wirtschaftsspionage-1.101852 ("1993 hatte US-Präsident Bill Clinton offiziell erklärt: CIA und NSA sollten amerikanischen Firmen bei internationalen Geschäften behilflich sein. Im «COMINT Auswirkungen auf den internationalen Handel» - Bericht an das Europäische Parlament wird auf diese US-Politik Bezug genommen: «Seit 1992 hat Europa wahrscheinlich merkliche Einbußen an Arbeitsplätzen und Einnahmen hinnehmen müssen.» Weiter heißt es: «Die Grenzen der Schätzungen liegen zwischen [einem Schaden von] 13 und 145 Milliarden US-Dollar.» Kritiker wenden ein, dass ein unanfechtbarer Fall aber bislang nicht nachgewiesen wurde. So resümmiert der EU-Bericht: «Die einzig sichere Beobachtung ist, dass man die genauen Zahlen niemals kennen wird. Aber es ist sehr wahrscheinlich, dass der wirtschaftliche Schaden für Europa bedeutend ist.»”). 
Thanks to the Echelon system, in an unverifiable way, one of the parties to the contract, breaking elementary ethical principles, becomes a de facto privileged entity, thus the rule of the equality of entities, not to mention confidentiality and good manners, completely fails!

What I am talking about has been the subject of many credible analyzes, including those of the European Parliament! ${ }^{19}$ But not of the Polish parliament!

\section{IV}

The fall of contract ethics, including contract law, is visible in what may be the subject of a contract.

I spoke about this in 2014 at the Fifth National Congress of Civil Lawyers in Poznan and grieved over the practice which has already spread. ${ }^{20}$ Non-transferable personal rights has begun the subject of contracts! It concerns not only the right to image or name, but also to privacy, the secret of correspondence, good name, or honor, the right to intimacy, not excluding birth and death, and skin covering the human body on which you can tattoo an advertisement, even the right to freedom of conscience and religion. The specialists in copyright law, following the Yankee path, even justify the contracting of authorship, i.e. a thing which is impossible to contracted by nature! ${ }^{21}$

19 Cf. European Parliament's resolution on the US National Security Agency surveillance programme, surveillance bodies in various Member States and the impact on EU citizens' privacy

(2013/2682(RSP),

http://www.europarl.europa.eu/sides/getDoc.do?type=TA\&reference=P7-TA-2013-

0322\&language=EN\&ring=B7-2013-0343. Cf. also: F. Patalong, "Echelon - Spionage unter Freunden”, http://www.spiegel.de/netzwelt/web/grosse-ohren-echelon-spionage-unterfreunden-a-71135.html ("Dass die Vereinigten Staaten und Großbritannien mit ihrem Abhörsystem "Echelon" die eigenen Verbündeten ausschnüffeln, war ein offenes Geheimnis. Jetzt ist es gar keines mehr: Das EU-Parlament debattierte und nannte das Kind endlich beim Namen. Hoch schlagen die Wellen vor allem in Frankreich. Der Vorwurf: Echelon betrieb gezielt Wirtschaftsspionage”).

20 Cf. J. Mazurkiewicz, “«Cześć, prywatność i zgon pilnie sprzedam!» Wokół dopuszczalności rozporządzania prawami osobistymi”. In A. Olejniczak, J. Haberko, A. Pyrzyńska, D. Sokołowska (eds.), Współczesne problemy prawa zobowiąań, Warszawa 2015, pp. 432-456.

21 Cf. J. Mazurkiewicz, “O uprzedmiotowieniu autorów, wszechwładzy wydawców i nędzy prawa autorskiego. Prawo autorskie w czasach restauracji kapitalizmu w Polsce”, Ruch Prawniczy, Ekonomiczny i Socjologiczny 2015, No. 2, pp. 251-262. Cf. M.J. Sandel, What Money Can't Buy. The Moral Limits of Markets, New York: Farrar, Straus and Giroux, 2013; P. Ondřejek, "Recenze: M.J. Sandel, What Money Can’t Buy. The Moral Limits of Markets”, Bulletin Advokacie 2012, No. 11, pp. 56-57 (I would like to thank the author of this valuable review, of the kind which is not very often today in Polish legal literature, for his unprecedented kindness shown during my professor internship at the Charles University in Prague). 
More and more "the market reduces everything, including human beings ... to the level of goods". ${ }^{22}$ It concern also, but primarily, the Polish market. Not only certain religious leaders and wise men warn against the threats which result from this state. ${ }^{23}$ Also a man, certainly "not from my story", George Soros - "the king of swindles of not only financial character" - does that. He reminds that "we can have a market economy, but we cannot have a market society" ${ }^{24}$

Without a doubt, it is not coquettish of me when I say that it is good for me to think that I will not live long enough to see the times when everything could be contracted!

\section{V}

I see particular threats to the foundations of contracting in the widespread use of electronic technologies. Today it is still only a fear, but I think that soon there will be times when finding a profitable or presenting an attractive offer will become impossible! And I do not think about the helplessness of both the entrepreneur and the consumer towards positioning.

The involvement of one of the most popular search engines in one of the US presidential candidates in $2016^{25}$ revealed opportunities that may soon

22 G. Soros, “Globalne społeczeństwo otwarte”, Rzeczpospolita 1997, No. 299, p. 8.

23 "An overturn is often understood as a positive change, for example the Copernican revolution. But there are also reverse, obscurantist revolutions. This is the case that Wojciech Sadurski tells me: things, phenomena, attitudes, formerly shamefully hidden, now are revealed willingly, even - with pride, they are displayed, eagerly, even with satisfaction! Ignorance, vulgarity, rudeness, brutality, lying - once condemned and embarrassing - now occur openly, nay, are considered a norm or even exalted. Jerzy Łoziński adds: yes, it's a Big Brother subculture, new pornography: show things formerly hidden. This is even emphasized as an advantage, as a new honesty. This is the highlight of the qualities that Ortega y Gasset saw in a man of mass culture - and that is complacency: look what I am! And I'm just great! I do not need to be different, better, wiser": R. Kapuściński, Lapidarium VI, Warszawa 2007, p. 92.

24 G. Soros, "Globalne społeczeństwo otwarte", Rzeczpospolita 1997, No. 299, p. 8. Cf. I. Wallerstein, R. Collins, M. Mann, G. Derluguian, C. Calhoun, Does Capitalism Have a Future?, Oxford - New York: Oxford University Press, 2013, pp. 71-98, 131-165.

25 M. Gavasheli, "Przełomowe odkrycie: Google jest kluczowym graczem w kampanii Clinton” (an interview with Epstein), http://pl.sputniknews.com/swiat/20160912/3853597/google-wybory-usa-clinton-trump.html; "Research Proves Google Manipulates Millions to Favor Clinton", https://sputniknews.com/us/201609121045214398-google-clinton-manipulation-

election/; “Google manipuluje wynikami wyborów”,

http://www.prawica.net/comment/65902; “Google manipuluje opinią publiczną w USA?”, http://m.chip.pl/news/internet-i-sieci/wyszukiwarki-internetowe/2016/06/google-

manipuluje-opinia-publiczna-w-usa; IAR, "Google oskarżony o manipulowanie wynikami wyszukiwarki. Koncern odpowiada na zarzuty KE”, http://www.polskieradio.pl/42/1699/Artykul/1643155,Google-oskarzony-o-manipulowaniewynikami-wyszukiwarki-Koncern-odpowiada-na-zarzuty-KE; K. Majdan, “Google grozi 
become a significant factor in the possibility of freedom of contract. Because of the fact that in the search engine you enter: "good and cheap light bulbs", when the search engine will be programmed so that you will never see the wanted offers, but those whose exposure depends on the search engine owner.

\section{VI}

The freedom of economic activity and - being a civil law necessity the principle of freedom of contract are one of the pillars of market capitalism.

And yet, often announced economic and trade sanctions are breaking both principles in a way that is incomparable to anything else. They are used against small, medium, and recently also the largest states, that is, those in which several, a few dozen, even close to one hundred and fifty million people live! And often for a dozen or even several dozen years! After all, they strike not only those people, but also the residents and entrepreneurs of the state introducing sanctions. Therefore, they concern people in relation to whom any fault, even imaginary, can be attributed.

In several cases, it turns out after many years that the circumstances indicated as reasons of (so far exclusively Western!) economic sanctions were a forgery. As in the case of a significant part of sanctions against Iraq. ${ }^{26}$ It was

rekordowa kara za manipulowanie wynikami wyszukiwania”, http://businessinsider.com.pl/technologie/firmy/3-mld-euro-kary-dla-google-za-

manipulowanie-wynikami-wyszukiwania/yz0ypbf; nab., “Manipuliert Google?”, http://www.faz.net/aktuell/wirtschaft/netzwirtschaft/google/hillary-clinton-kampangnemanipuliert-google-14281390.html; C. Dobschat, "Manipuliert Google zugunsten von Hillary Clinton?”, https://www.mobilegeeks.de/news/manipuliert-google-zugunsten-von-hillaryclinton/; E. Javers, "Clinton camp asked Apple, Google for opinion of Clinton encryption comments”, $\quad$ http://www.cnbc.com/2016/10/20/clinton-camp-asked-apple-google-foropinion-of-clinton-encryption-comments.html; R. Sasse, "Hillary Clinton: So manipuliert Google Suchergebnisse!”, http://www.watergate.tv/2016/10/18/google-manipuliertsuchergebnisse-fuer-hillary-clinton/. Cf. also: D. Anderson, "Google Allegedly Manipulating Search Results Favoring Big Brands Over Small Businesses”, http://www.infowars.com/google-allegedly-manipulating-search-results-favoring-bigbrands-over-small-businesses/; “Ausweitung der Werbezone: So manipuliert Google”, http://www.computerbild.de/artikel/cb-Aktuell-Internet-Google-Manipulation-

Suchmaschine-Werbung-8234409.html; T. Kleinz, "Studie: Google manipuliert Suchergebnisse”, http://www.heise.de/newsticker/meldung/Studie-Google-manipuliertSuchergebnisse-2731456.html; "Wie Google bei der Suche manipuliert", https://www.welt.de/wirtschaft/webwelt/gallery115174683/Wie-Google-bei-der-Suchemanipuliert.html; M.J. Stern, "Yes, Google Manipulated Its Search Results. It’s Probably Allowed To", http://www.slate.com/blogs/future_tense/2015/03/20/google_manipulated_its_search_results _the_first_amendment_protects_that.html.

26 The literature on this subject is enormous. Therefore, I will mention only one of the earliest and unique Polish publications: Będziemy walczyć do ostatniego dziecka ["We will fight to the last child"], an interview of Zofia Zaporowska and Michał Matusiewicz with Faisal B. 
also indirectly, but clearly, said on 24 March 2016, when International Criminal Tribunal for the former Yugoslavia assessed the conditions for introducing sanctions against Yugoslavia. In the conviction concerning Radovan Karadžić, this tribunal could not acquit Slobodan Milošević who died in puzzling circumstances ten years ago in The Hugue's jail, so it only stated that no evidence was found confirming any of the 66 charges against Milošević, adding that charging him was a mistake. ${ }^{27}$

It is very difficult to find this information in the few Polish media, ${ }^{28}$ although the above-mentioned Hague judgment can be found on the internet ${ }^{29}$

Hussein, Wrocław 2003, pp. $3 \mathrm{ff}$.

27A. Kwaśniewski, “«Okazja do wojny» lub casus belli”, https://pl.sputniknews.com/blogs/201611014169348-okazja-do-wojny-kwasniewski-blog/.

Cf. M. Waldenberg, Narody zależne $i$ mniejszości narodowe $w$ Europie ŚrodkowoWschodniej. Dzieje konfliktów i idei, Warszawa 2000, pp. 447-448.

28 Cf. A. Wilcoxson, "The Exoneration of Milosevic: the ICTY's Surprise Ruling”, http://www.counterpunch.org/2016/08/01/the-exoneration-of-milosevic-the-ictys-surprise-

ruling/ ("The International Criminal Tribunal for the Former Yugoslavia (ICTY) in The Hague has determined that the late Serbian president Slobodan Milosevic was not responsible for war crimes committed during the 1992-95 Bosnian war ... The Tribunal's determination that Slobodan Milosevic was not part of a joint criminal enterprise, and that on the contrary he «condemned ethnic cleansing» is of tremendous significance because he got blamed for all of the bloodshed in Bosnia, and harsh economic sanctions were imposed on Serbia as a result. Wrongfully accusing Milosevic ranks right up there with invading Iraq only to find that there weren't any weapons of mass destruction after all. Slobodan Milosevic was vilified by the entire western press corps and virtually every politician in every NATO country. They called him «the Butcher of the Balkans.» They compared him to Hitler and accused him of genocide. They demonized him and made him out to be a bloodthirsty monster, and they used that false image to justify not only economic sanctions against Serbia, but also the 1999 NATO bombing of Serbia and the Kosovo war. Slobodan Milosevic had to spend the last five years of his life in prison defending himself and Serbia from bogus war crimes allegations over a war that they now admit he was trying to stop. The most serious charges that Milosevic faced, including the charge of genocide, were all in relation to Bosnia. Now, ten years after his death, they admit that he wasn't guilty after all - oops"); A. Wilcoxson, "Hague Tribunal Exonerates Slobodan Milosevic for Bosnia War Crimes Ten Years Too Late", http://www.slobodanmilosevic.org/news/smorg-aw071816.htm; "Milošević offiziell nicht für Kriegsverbrechen schuld”, http://www.kosmo.at/milosevic-offiziell-nicht-fuer-kriegsverbrechen-schuld/ ("Der Westen schweigt darüber, dass Den Haag Milošević vom Verdacht auf Kriegsvebrechen und ethnische Säuberung freigesprochen wurde, aber Serbien darf nicht schweigen“, so der serbische Außenminister und Vize-Regierungschef Serbiens Ivica Dačić ... Gleichzeitig veröffentlichte der amerikanische Publizist Andy Wilcoxon eine Analyse über die Verurteilung von Radovan Karadžić und unterstreicht mit diesem Artikel, dass der Den Haager Richter mit der Urteilsverkündung bestätigte, dass Milošević nicht in die Kriegsverbrechen, welche Karadžić begangen hat, involviert war").

29 International Tribunal for the Prosecution of Persons Responsible for Serious Violations of International Humanitarian Law Committed in the Territory of the former Yugoslavia since 1991, Case No.: IT-95-5/18-T, Prosecutor v. Radovan Karadžić, public redacted version of judgement issued on 24 March 2016, volume I of IV, 
I mention this because almost no one in the EU and NATO, including Poland, thinks today about what justified the unprecedented violation of not only the freedom of economic activity and the freedom of contract that affected millions of people in the former Yugoslavia and elsewhere. ${ }^{30}$

At the end I will present a digression. The adherent of sanctions, some Junckers $^{31}$ et consortes, continue to spice up a dish that would be the Transatlantic Trade and Investment Partnership (TTIP) ${ }^{32}$ or an appetizer before it, i.e. the Comprehensive Economic and Trade Agreement (CETA), ${ }^{33}$ thanks to which you and I will not have the right - just one example ${ }^{34}$ - to learn how undesirable is the food which we buy and eat in our own country. ${ }^{35}$ For this company ethics means less than a fake address!

http://www.icty.org/x/cases/karadzic/tjug/en/160324_judgement.pdf.

30 Cf. also: M. Waldenberg, Rozbicie Jugostawii. Od separacji Stowenii do wojny kosowskiej, Warszawa 2003, pp. 97-98; M. Waldenberg, Rozbicie Jugosławii - jugostowiańskie lustro międzynarodowej polityki, Vol. I: 1991-2002, Vol. II: 2002-2004, Warszawa 2005, p. 102; Лавров назвал агрессией бомбардировки Югославии войсками НАТО, https://ria.ru/world/20161031/1480323318.html.

31 Cf. K. Strzępka, “CETA wisi na włosku: Juncker zapowiada kolejne negocjacje na piątek”, http://wiadomosci.onet.pl/swiat/ceta-wisi-na-wlosku-juncker-zapowiada-kolejne-negocjacjena-piatek/zmmkwd

32 Cf. "Stany Zjednoczone nie cofną się przed niczym, żeby osłabić gospodarkę UE", http://pl.sputniknews.com/gospodarka/20160122/1897030/USA-Europa-TTIP.html.

33 "CETA: Wie die Europäische Union (EU) trickst + Anti-CETA-Volksbegehren in Österreich”, http://www.euaustrittspartei.at/eu-nein-danke/ceta/; “Der Begriff Freihandelsabkommen ist ein Lügenwort”, http://www.deutschlandfunk.de/sahrawagenknecht-zu-ceta-der-begriff-

freihandelsabkommen.694.de.html?dram:article_id=368352; M. Krukowska, "Tajemnicza umowa z USA. Co nas czeka po jej podpisaniu?”, http://csr.forbes.pl/ttip-co-dla-nasoznacza-umowa-handlowa-z-

usa,artykuly,203543,1,1.html; J. Augustyniak, "Nie udało się im TTIP. Będzie CETA”, https ://pl.sputniknews.com/opinie/201610124042528-Nie-udalo-sie-im-TTIP-Bedzie-CETA-

Jaroslaw-Augustyniak/; J. Ceglarz, "W Warszawie protesty przeciwko CETA. Czy polski rząd się ugnie?”, http://agrobiznes.money.pl/artykul/ceta-ttip-protest-isdskary,113,0,2170481.html; "CETA zostanie podpisana”, https://pl.sputniknews.com/gospodarka/201610304160048-ceta-zostanie-podpisana/.

34 "McDonald's pozwał Florencję. Chce 20 mld dolarów", http://wiadomosci.onet.pl/swiat/mcdonalds-pozwala-wloskie-miasto-chce-20-mld-dolarowod-florencji/jvj6v7.

35 Cf., e.g., L. Sigan, “CETA: boimy się o zdrowie i bezpieczeństwo konsumentów”, https://pl.sputniknews.com/polska/201610314167091-ceta-unia-europejska-kanada/; “CETA - czy już czas się bać?”, http://krytykkulinarny.pl/2016/10/ceta-czy-juz-czas-sie-bac/. 


\section{VII}

I said what I said, out of concern, which - as you can see - cannot be hidden by me, even if it could unreasonable.

I have presented this concern with a hope that among young scholars there are those who will make significant research on subjects mentioned here. Those who will look at the law of contracts wider than it used to be done so far! Maybe they will have enough courage to deal with these topics from a Marxian perspective. Not only because it is an intriguing area of research, but also because in the face of injustice, harm and evil, one cannot remain silent, and keep at the same time dignity and a good name.

\section{Conclusions}

Contemporary contract law loses its moral and social function. The fundamental principle of the equality of parties often turns out to be fiction in practice of contract law. Goods which should be contracted on moral grounds are now becoming the object of contracts. The trust of parties that conclude contracts sometimes is undermined by economic intelligence organized by some countries. The widespread use of electronic technologies sometimes exposes a weaker party to the contract on fraudulent manipulations by a stronger party. The principle of freedom of economic activity is often ostentatiously violated due to announced economic and commercial sanctions.

\section{References}

1. Anderson D., Google Allegedly Manipulating Search Results Favoring Big Brands Over Small Businesses, http://www.infowars.com/googleallegedly-manipulating-search-results-favoring-big-brands-oversmall-businesses/

2. Andreasik M., Karkut D., Mazurkiewicz J., Mierzwiński B., Popielas M., Trzeciak K., Zaporowska M., Zaporowska Z., "Orwell w realu, czyli o systemie Echelon z perspektywy polskiego prawa”, Studia Prawnicze. Rozprawy i Materiaty 2014, No. 2.

3. Augustyniak J., Nie udato się im TTIP. Będzie CETA, https://pl.sputniknews.com/opinie/201610124042528-Nie-udalo-sieim-TTIP-Bedzie-CETA-Jaroslaw-Augustyniak/

4. Ausweitung der Werbezone: So manipuliert Google, http://www.computerbild.de/artikel/cb-Aktuell-Internet-Google-

Manipulation-Suchmaschine-Werbung-8234409.html

5. Będziemy walczyć do ostatniego dziecka, interview of Zofia Zaporowska and Michał Matusiewicz with Faisal B. Hussein, Wrocław 2003.

6. Brzozowski A. In Kodeks cywilny, Vol. I, Art. 1-44910, edited by K. Pietrzykowski, Warszawa 2013. 
7. Ceglarz J., W Warszawie protesty przeciwko CETA. Czy polski rzad sie ugnie?, http://agrobiznes.money.pl/artykul/ceta-ttip-protest-isdskary,113,0,2170481.html

8. CETA - czy już czas się bać?, http://krytykkulinarny.pl/2016/10/cetaczy-juz-czas-sie-bac/

9. CETA: Wie die Europäische Union (EU) trickst + Anti-CETAVolksbegehren in Österreich, http://www.euaustrittspartei.at/eu-neindanke/ceta/

10. CETA zostanie

podpisana, https://pl.sputniknews.com/gospodarka/201610304160048-cetazostanie-podpisana/

11.Der Begriff Freihandelsabkommen ist ein Lügenwort, http://www.deutschlandfunk.de/sahra-wagenknecht-zu-ceta-derbegriff-freihandelsabkommen.694.de.html?dram:article_id=368352

12.dkl, DPA, NSA sorgte schon vor 9/11 für Ärger, http://www.n24.de/n24/Wissen/Technik/d/3070112/nsa-sorgte-schonvor-9-11-fuer-aerger.html

13. Dobschat C., Manipuliert Google zugunsten von Hillary Clinton?, https://www.mobilegeeks.de/news/manipuliert-google-zugunstenvon-hillary-clinton/

14. Duguit L., Kierunki rozwoju prawa cywilnego od poczatku XIX wieku, translated by S. Sieczkowski, Warszawa-Kraków 1938.

15. Duguit L., L'état, le droit objectif et la loi positive, Paris 1901.

16. Duguit L., Traité de droit constitutionel, Vol. I, Paris 1921.

17. Echelon, https://pl.wikipedia.org/wiki/Echelon

18. Engels F., Condition of the Working Class in England, https://www.marxists.org/archive/marx/works/download/pdf/conditio n-working-class-england.pdf.

19. European Parliament's resolution on the US National Security Agency surveillance programme, surveillance bodies in various Member States and the impact on EU citizens' privacy (2013/2682(RSP), http://www.europarl.europa.eu/sides/getDoc.do?type=TA\&reference $=\mathrm{P} 7-\mathrm{TA}-2013-0322$ \&language $=\mathrm{EN} \&$ ring $=\mathrm{B} 7-2013-0343$.

20. Gavasheli M., Przełomowe odkrycie: Google jest kluczowym graczem w kampanii Clinton, wywiad z R. Epsteinem, http://pl.sputniknews.com/swiat/20160912/3853597/google-wyboryusa-clinton-trump.html

21. German politician claims TTIP and CETA fraught with risk of geopolitical confrontation, http://tass.com/world/911781

22. Google manipuluje opinia publiczna wUSA?, http://m.chip.pl/news/internet-i-sieci/wyszukiwarkiinternetowe/2016/06/google-manipuluje-opinia-publiczna-w-usa 
23. Google

manipuluje

wynikami

wyborów, http://www.prawica.net/comment/65902

24. http://katalog.nukat.edu.pl/lib/item?id=chamo:788411\&theme=nukat

25. http://www.faz.net/aktuell/wirtschaft/netzwirtschaft/google/hillaryclinton-kampangne-manipuliert-google-14281390.html

26. IAR, Google oskarżony o manipulowanie wynikami wyszukiwarki. Koncern odpowiada na zarzuty KE, http://www.polskieradio.pl/42/1699/Artykul/1643155,Googleoskarzony-o-manipulowanie-wynikami-wyszukiwarki-Koncernodpowiada-na-zarzuty-KE

27. International Tribunal for the Prosecution of Persons Responsible for Serious Violations of International Humanitarian Law Committed in the Territory of the former Yugoslavia since 1991, Case No.: IT-955/18-T, Prosecutor v. Radovan Karadžić, public redacted version of judgement issued on 24 March 2016, volume i of iv, http://www.icty.org/x/cases/karadzic/tjug/en/160324_judgement.pdf

28. Janiak A. In Kodeks cywilny. Komentarz, Vol. I, Czesść ogólna, edited by A. Kidyba, Warszawa 2012.

29. Javers E., Clinton camp asked Apple, Google for opinion of Clinton encryption comments, http://www.cnbc.com/2016/10/20/clintoncamp-asked-apple-google-for-opinion-of-clinton-encryptioncomments.html

30. Jhering R. von, Der Kamp um's Recht, Wien 1874.

31. Jhering R. von, Der Zweck im Recht, Leipzig 1893.

32. Jhering R. von, Geist des römischen Rechts auf den verschiedenen Stufen seiner Entwicklung, Vol. III, Leipzig 1865.

33. Kapuściński R., Lapidarium VI, Warszawa 2007.

34. Kleinz T., Studie: „Google manipuliert Suchergebnisse”, http://www.heise.de/newsticker/meldung/Studie-Google-manipuliertSuchergebnisse-2731456.html

35. Kopaczyńska-Pieczniak K. In Kodeks cywilny. Komentarz, Vol. I, Część ogólna, edited by A. Kidyba Warszawa 2012.

36. Koschembahr-Łyskowski I., "O stanowisku prawa rzymskiego w powszechnej ustawie cywilnej dla Cesarstwa Austryackiego". In Księga pamiatkowa wydana w setna rocznice ogłoszenia kodeksu cywilnego z dnia 1. Czerwca 1811 roku, staraniem Wydziału Prawa i Nauk Politycznych Uniwersytetu Lwowskiego, Lwów 1911.

37. Koschembahr-Łyskowski I., "Pojęcie prawa". In Księga pamiątkowa ku uczczeniu 250-tej rocznicy założenia Uniwersytetu Lwowskiego przez króla Jana Kazimierza r. 1661, Vol. I, Lwów 1912.

38. Koszmarny sen Snowdena: w Holandii opracowano własna wersje „pakietu

Jarowej", 
https://pl.sputniknews.com/opinie/201611074198491-snowdenpakiet-jarowej-holandia/

39. Krukowska M., Tajemnicza umowa z USA. Co nas czeka po jej podpisaniu?, http://csr.forbes.pl/ttip-co-dla-nas-oznacza-umowahandlowa-z-usa,artykuly,203543,1,1.html

40. Księżak P. In Kodeks cywilny. Część ogólna. Komentarz, edited by M. Pyziak-Szafnicka, P. Księżak, Warszawa 2014.

41. Лавров назвал агрессией бомбардировки Югославии войсками HATO, https://ria.ru/world/20161031/1480323318.html

42. Kwaśniewski A., „Okazja do wojny” lub casus belli, https://pl.sputniknews.com/blogs/201611014169348-okazja-dowojny-kwasniewski-blog/

43. Machnikowski P., Prawne instrumenty ochrony zaufania przy zawieraniu umowy, Wrocław 2010.

44. Machnikowski P. In Kodeks cywilny. Komentarz, edited by E. Gniewek, P. Machnikowski, Warszawa 2014.

45. Majdan K., Google grozi rekordowa kara za manipulowanie wynikami wyszukiwania, http://businessinsider.com.pl/technologie/firmy/3-mldeuro-kary-dla-google-za-manipulowanie-wynikamiwyszukiwania/yz0ypbf

46. Marks K., Krytyka Programu Gotajskiego. In K. Marks, F. Engels, Dzieła, Vol. 19, Warszawa 1972.

47. Mazurkiewicz J., "Co może obywatel w demokratycznym państwie prawnym?” In J. Mazurkiewicz, J. Mazurkiewicz, M. Zaporowska, Z. Zaporowska, "Wieniec laurowy dla Profesora Jerzego Ignatowicza (pięć prawniczych miniatur)". In Prawo cywilne - stanowienie, wykladnia i stosowanie. Ksiegga pamiatkowa dla uczczenia setnej rocznicy urodzin Profesora Jerzego Ignatowicza, edited by M. Nazar, Lublin 2015.

48. Mazurkiewicz, “«Cześć, prywatność i zgon pilnie sprzedam!» Wokół dopuszczalności rozporządzania prawami osobistymi”. In Wspótczesne problemy prawa zobowiqzań, edited by A. Olejniczak, J. Haberko, A. Pyrzyńska, D. Sokołowska,Warszawa 2015.

49. Mazurkiewicz J., "O uprzedmiotowieniu autorów, wszechwładzy wydawców i nędzy prawa autorskiego. Prawo autorskie w czasach restauracji kapitalizmu w Polsce", Ruch Prawniczy, Ekonomiczny $i$ Socjologiczny 2015, No. 2.

50. Mazurkiewicz J., "Recenzja pracy K. Sójki-Zielińskiej pt. Wielkie kodyfikacje cywilne w XIX wieku”, Przeglad Prawa i Administracji 1976, Vol. VII. 
51. McDonald's pozwat Florencję. Chce 20 mld dolarów, http://wiadomosci.onet.pl/swiat/mcdonalds-pozwala-wloskie-miastochce-20-mld-dolarow-od-florencji/jvj6v7

52. nab., Manipuliert Google?, http://www.faz.net/aktuell/wirtschaft/netzwirtschaft/google/hillaryclinton-kampangne-manipuliert-google-14281390.html

53. Olejniczak A., "O ochronie poufności negocjacji w świetle art. $72^{1}$ Kodeksu cywilnego”. In W kierunku europeizacji prawa prywatnego. Księga pamiątkowa dedykowana profesorowi Jerzemu Rajskiemu, edited by A. Brzozowski, W. Kocot, K. Michałowska, Warszawa 2007.

54. Ondřejek P., "Recenze: M.J. Sandel, What Money Can’t Buy. The Moral Limits of Markets”, Bulletin Advokacie 2012, No. 11.

55. Patalong F., Echelon - Spionage unter Freunden, http://www.spiegel.de/netzwelt/web/grosse-ohren-echelon-spionageunter-freunden-a-71135.html

56. Pyziak-Szafnicka M. In Kodeks cywilny. Część ogólna. Komentarz, edited by M. Pyziak-Szafnicka, P. Księżak, Warszawa 2014.

57. Research Proves Google Manipulates Millions to Favor Clinton, https://sputniknews.com/us/201609121045214398-google-clintonmanipulation-election/

58. Reszka P., Chciwość. Jak nas oszukuja wielkie firmy, Warszawa 2016.

59. Robaczyński W. In Kodeks cywilny. Czesść ogólna. Komentarz, edited by M. Pyziak-Szafnicka, P. Księżak, Warszawa 2014.

60. Safjan M. In Kodeks cywilny, t. I, Art. 1-449 ${ }^{10}$, edited by K. Pietrzykowski, Warszawa 2013.

61. Sandel M.J., What Money Can't Buy. The Moral Limits of Markets, New York: Farrar, Straus and Giroux, 2013.

62. Sasse R., Hillary Clinton: So manipuliert Google Suchergebnisse!, http://www.watergate.tv/2016/10/18/google-manipuliertsuchergebnisse-fuer-hillary-clinton/

63. Schmitt S., S., Wirtschaftsspionage, http://www.sueddeutsche.de/digital/streit-um-echelonwirtschaftsspionage-1.101852

64. Sigan L., CETA: boimy się o zdrowie i bezpieczeństwo konsumentów, https://pl.sputniknews.com/polska/201610314167091-ceta-uniaeuropejska-kanada/

65. Simoner M., Die Allesfresser der Spionage, http://derstandard.at/1369363266451/Die-Allesfresser-der-Spionage

66. Sołtysiński S., "Ład korporacyjny w świetle lekcji kryzysu”, Kwartalnik Prawa Prywatnego 2011, No. 1. 
67. Sołtysiński S., "O potrzebie powstrzymania procesów nierównego traktowania podmiotów gospodarczych", Kwartalnik Prawa Prywatnego 2015, No. 3.

68. Soros G., "Globalne społeczeństwo otwarte", Rzeczpospolita 1997, No. 299.

69. Sójka-Zielińska K., Wielkie kodyfikacje cywilne wXIX wieku, Warszawa 1973.

70. Stany Zjednoczone nie cofna się przed niczym, żeby osłabić gospodarke

$U E$, http://pl.sputniknews.com/gospodarka/20160122/1897030/USAEuropa-TTIP.html

71. Stelmachowski A., Kościól katolicki w Polsce wobec wyzwań liberalizmu, Lublin 1996.

72. Stelmachowski A., Wstep do teorii prawa cywilnego, Warszawa 1969.

73. Stelmachowski A., Wstęp do teorii prawa cywilnego, 2 edition, Warszawa 1984.

74. Stern M.J., Yes, Google Manipulated Its Search Results. It's Probably Allowed http://www.slate.com/blogs/future_tense/2015/03/20/google_manipul ated_its_search_results_the_first_amendment_protects_that.html

75. Strzępka K., CETA wisi na włosku: Juncker zapowiada kolejne negocjacje na piatek, http://wiadomosci.onet.pl/swiat/ceta-wisi-nawlosku-juncker-zapowiada-kolejne-negocjacje-na-piatek/zmmkwd

76. Till E., Józef Unger - Wpływ jego na naukę prawa prywatnego, Lwów 1913.

77. "Uhonorowanie Profesora Stanisława Sołtysińskiego, streszczenie wykładu S. Sołtysińskiego pt. Ład korporacyjny w świetle lekcji kryzysu”, Przeglad Prawa Handlowego 2010, No. 6.

78. Waldenberg M., Narody zależne i mniejszości narodowe w Europie Środkowo-Wschodniej. Dzieje konfliktów i idei, Warszawa 2000.

79. Waldenberg M., Rozbicie Jugosławii - jugostowiańskie lustro międzynarodowej polityki, Vol. I: 1991-2002, Vol. II: 2002-2004, Warszawa 2005.

80. Waldenberg M., Rozbicie Jugosławii od separacji Słowenii do wojny kosowskiej, Warszawa 2003.

81. Wallerstein I., Collins R., Mann M., Derluguian G., Calhoun C., Does Capitalism Have a Future?, Oxford - New York: Oxford University Press, 2013.

82. Wie Google bei der Suche manipuliert, https://www.welt.de/wirtschaft/webwelt/gallery115174683/WieGoogle-bei-der-Suche-manipuliert.html 
83. Wilcoxson A., Hague Tribunal Exonerates Slobodan Milosevic for Bosnia War Crimes Ten Years Too Late, http://www.slobodanmilosevic.org/news/smorg-aw071816.htm

84. Wilcoxson A., The Exoneration of Milosevic: the ICTY's Surprise Ruling, http://www.counterpunch.org/2016/08/01/the-exoneration-ofmilosevic-the-ictys-surprise-ruling/

85. Wołodkiewicz W., "Studia prawnicze - nauka przepisów czy nauka prawa”. In Noctes iurisprudentiae. Scritti in onore di Jan Zabłocki, edited P. Niczyporuk and A. Tarwacka, Białystok 2015.

86. Zaporowska Z., Matusiewicz M., "Narodowcy z Narodowej”, Nie 2004, No. 50.

87. Zaporowski P., Mazurkiewicz J. (ed.), Zaporowska M., Zaporowska Z., Polskie prawo firmowe. Zagadnienia wybrane, Wrocław 2016, http://www.bibliotekacyfrowa.pl/dlibra/docmetadata?id=76594\&fro $\mathrm{m}=$ publication

88. Zimmerman M., Być rekinem i zjadać frajerów, czyli jak nas oszukaty wielkie firmy, http://biznes.onet.pl/wiadomosci/finanse/jak-oszukujawielkie-firmy-bankowcy-agenci-ubezpieczeniowi/q8v7m5 